\title{
Monitoring Ceratomyxa shasta infection during a hatchery rearing cycle: comparison of molecular, serological and histological methods
}

\author{
Jerri L. Bartholomew ${ }^{1,2, *}$, E. Ray ${ }^{4}$, B. Torell ${ }^{5}$, M. J. Whipple ${ }^{4}$, J. R. Heidel ${ }^{2,3}$ \\ ${ }^{1}$ Department of Microbiology, Oregon State University, 220 Nash Hall, ${ }^{2}$ Center for Fish Disease Research, \\ Oregon State University, 220 Nash Hall, and ${ }^{3}$ College of Veterinary Medicine, Oregon State University, \\ 134 Magruder Hall, Corvallis, Oregon 97331-3804, USA \\ ${ }^{4}$ Washington Department of Fish and Wildlife, 1111 Washington Street SE, Olympia, Washington 98504, USA \\ ${ }^{5} 911$ Jefferson Street, Oregon City, Oregon 97045, USA
}

\begin{abstract}
The prevalence of Ceratomyxa shasta infection in production stocks of steelhead Oncorhynchus mykiss and cutthroat trout $O$. clarki was monitored using a parasite-specific polymerase chain reaction (PCR) assay. For all 4 stocks of fish followed through their 1 yr rearing cycle, C. shasta infection was detected despite their genetic resistance to the disease and the treatment of the incoming water with ozone. Infection was confirmed using serological methods and standard histological procedures, except when prevalence was low $(<10 \%)$. This suggests that at the lowest infection levels PCR is more sensitive than other methodologies, and can be used as an early indicator of infection. Results of the PCR assay continued to correlate with histological and serological detection as the numbers of parasites and the lesion severity increased over the rearing cycle. For both steelhead and cutthroat trout, early infections were characterized by large numbers of parasites on the epithelial surface, but with little associated inflammation. At release as yearlings, the infection prevalence in all stocks was greater than $90 \%$ and the inflammatory response in many fish was extensive, with tissue necrosis and mucosal damage. Although $C$. shasta infections no longer result in high mortality at this facility, results of this study indicate that the parasite remains a contributor to low condition indices in these fish, despite their genetic resistance and ozone disinfection of the water supply.
\end{abstract}

KEY WORDS: Ceratomyxa shasta $\cdot$ Salmonid disease $\cdot$ Myxozoan $\cdot$ Ozone $\cdot$ Disease resistance

\section{INTRODUCTION}

Ceratomyxosis is a disease of salmonid fish that results from infection by the myxozoan Ceratomyxa shasta. In susceptible fish, clinical disease signs include lethargy, darkening of the body surface, abdominal distension and hemorrhaging in the area of the vent (Conrad \& Decew 1966, Schafer 1968, Bartholomew et al. 1989a). These signs develop as the parasite invades the intestinal tract, causing an inflammatory reaction and necrosis. Similar to the described life cycles of other myxozoans (reviewed by Kent et al. 2001), C. shasta requires 2 hosts in which alternating spore stages develop. The actinospore stage develops in a freshwater polychaete worm, Manayunkia speciosa (Bartholomew et al. 1997), while most species of the family Salmonidae can serve as hosts for the myxospore stage (Bartholomew 1998).

The geographic range of Ceratomyxa shasta is limited to the Pacific Northwest region of the United States and Canada, where it has been documented in several major river drainages, including the Sacramento, Klamath, Rogue, Columbia and Fraser (Bartholomew et al. 1989b, Hendrickson et al. 1989). Salmonids native to these waters have a decreased susceptibility to ceratomyxosis relative to strains of the same species from nonenzootic waters, and thus are considered 'resistant'. 
The Cowlitz River, Washington, USA, is a tributary of the lower Columbia River, and Ceratomyxa shasta is enzootic throughout its lower 105 river kilometers (RKM). Construction of 2 major hydroelectric dams and a barrier dam, completed in 1968, impacted anadromous fish runs on the Cowlitz. To supplement the natural production and mitigate the effects of the dams, 2 hatcheries were built. At the Cowlitz Salmon Hatchery, located just above the barrier dam (RKM 80.5), $C$. shasta infection caused an epizootic during the first years of operation in the late 1960s. Since then, $C$. shasta spores have been found only occasionally during post mortem examinations, and mortality related to the infection has not been significant. At the Cowlitz Trout Hatchery (CTH), located $13 \mathrm{~km}$ downstream from the dams (RKM 69.2), C. shasta infections have been severe. From 1980 to 1985, mortality among the 3 stocks of steelhead Oncorhynchus mykiss and sea-run cutthroat trout O. clarki ranged between 38 and 90\% annually, and many survivors were undersized and likely had poor ocean survival (Tipping 1988). With the implementation of an ozone system at the $\mathrm{CTH}$ in 1991, mortality attributed to ceratomyxosis declined to between 6 and $14 \%$ in the 2 years following operation.

A comprehensive study to document the effects of the Cowlitz River hydroelectric projects on hatchery and wild salmonid populations in the Cowlitz River was initiated in 1998. This provided an opportunity to test a Ceratomyxa shasta-specific polymerase chain reaction (PCR) assay (Palenzuela et al. 1999, Fox et al. 2000, Palenzuela \& Bartholomew 2002) as a tool for monitoring hatchery populations, and to examine the effects of prolonged exposure to $C$. shasta in fish that have a high level of genetic resistance to the disease.

\section{MATERIALS AND METHODS}

Fish rearing. Three stocks of steelhead (summer, early winter, late winter) and sea-run cutthroat trout are raised at the CTH. Summer steelhead and sea-run cutthroat hatch by January, winter steelhead hatch in early February and late winter steelhead hatch in late May. For all stocks, fertilized eggs and fry are incubated and reared on well water until river water temperatures exceed $10^{\circ} \mathrm{C}$, typically in May. From May until river temperatures are consistently less than $10^{\circ} \mathrm{C}$ (November or December), the fish are reared on river water treated with ozone at $2 \mathrm{ppm}$. After a $15 \mathrm{~min}$ retention time, residual ozone ( 0.1 to $0.2 \mathrm{ppm})$ is removed in a forced-air, packed tower stripping unit prior to entering the raceway. After water temperatures drop, fish are reared on untreated river water until they are released as yearlings in late April or early May (Table 1).
Sample collection. For the 1999 brood year, 60 fish of each stock were sampled once prior to ozone water treatment, twice during rearing on river water treated with ozone, twice after ozone treatment, then at approximately 2 mo intervals until their release (Table 1). At collection, fish were euthanized by overdose with tricane methanesulfonate (500 $\mathrm{mg} \mathrm{l}^{-1}$ ) and each fish was weighed and measured. The visceral cavity was opened and a small piece of the intestine (approximately 2 to $5 \mathrm{~mm}$ ) was cut from the posterior region for PCR, using a new razor blade for each fish. The tissue was transferred to a $2 \mathrm{ml}$ screw cap vial containing $500 \mu$ of DNA extraction buffer (100 mM NaCl, $10 \mathrm{mM}$ Tris-Hcl, 25 mM EDTA, $1 \%$ w/v SDS, pH 8) (Palenzuela et al. 1999). For histological analysis, a portion of the intestine anterior to that collected for PCR was excised and transferred to a tube containing $10 \%$ neutral buffered formalin. All samples were coded so that individual fish could be identified.

PCR analysis. Prior to PCR assay, samples were further digested by addition of $200 \mu \mathrm{g} \mathrm{ml}^{-1}$ Proteinase $\mathrm{K}$ to the DNA extraction buffer and incubation at $37^{\circ} \mathrm{C}$ for at least $8 \mathrm{~h}$ on a rotational rocker. Pancreatic RNase A (5 Prime 3 Prime) was added to a final concentration of $100 \mu \mathrm{g} \mathrm{ml}^{-1}$ to each sample and samples were rotated at $37^{\circ} \mathrm{C}$ for $1 \mathrm{~h}$. After enzymatic treatment, samples were boiled for $5 \mathrm{~min}$, diluted 1:100 with HPLC grade water and assayed for presence of Ceratomyxa shasta DNA using conditions for the single round PCR (Palenzuela et al. 1999, Palenzuela \& Bartholomew 2002). Samples from rainbow trout Oncorhynchus mykiss reared on well water at the Oregon State University Salmon Disease Laboratory, Corvallis, were interspersed with samples from exposed fish to monitor cross-contamination and false-positives. Ten $\mu$ of each reaction product was electrophoresed in a $1 \%$ agarose gel containing ethidium bromide, and visualized with UV illumination. An amplification product of $638 \mathrm{bp}$ indicated presence of C. shasta DNA.

Histological analysis. For each sample period, 8 to 10 fish were selected for histological analysis. Selection was based on PCR results, to include at least 1 negative sample, with the remainder of samples from fish that were PCR-positive. Tissues from fish of 1 stock at a sample period were processed together using standard histological methods, with no attempt to retain the original fish identification code. Three $5 \mu \mathrm{m}$ sections cut from each tissue block were mounted separately. One slide was retained for staining with a Ceratomyxa shasta-specific monoclonal antibody (Bartholomew et al. 1989c); the other 2 were stained with hematoxylin and eosin or May-Grünwald Giemsa and examined microscopically to determine lesion severity. Lesions were scored from 0 to 5 (Fig. 1) using the following guidelines: (0) no parasites or inflamma- 
tory response; (1) minimal-parasites localized, inflammation minimal or absent; (2) mild - multiple discrete inflammatory foci surrounding organisms, no mucosal damage, no necrosis; (3) moderate-multiple confluent inflammatory and necrotic foci, minimal mucosal involvement, parasites and necrotic cells in lumen; (4) moderate-severe-multiple confluent inflammatory and necrotic foci, severe mucosal involvement; (5) severe-diffuse transmural inflammation and necrosis, organisms and necrotic cells occlude intestinal lumen, sporogenesis may be evident.

Indirect fluorescent antibody technique (IFAT). Tissue sections were stained using a monoclonal antibody specific for trophozoite stages of Ceratomyxa shasta as described by Bartholomew et al. (1989c). Briefly, sections were deparaffinized in two $15 \mathrm{~s}$ changes of xylene and hydrated in three $15 \mathrm{~s}$ changes of $95 \%$ ethanol, followed by $5 \mathrm{~min}$ in phosphate-buffered saline (PBS). Sections were incubated with monoclonal antibody for $1 \mathrm{~h}$ at room temperature, rinsed with $\mathrm{PBS}$, and incubated with a fluorescein-conjugated anti-mouse immunogolobulin (Sigma Chemical) for $30 \mathrm{~min}$. Methyl green dye (1\% in distilled water) was used as a counterstain. Sections were examined using a Zeiss standard microscope with an IV Fl epifluoresence condenser. Numbers of parasites were recorded for each tissue section.

Condition factor. Lengths and weights were recorded for each sample to determine the condition factor (Piper et al. 1982). $t$-tests were performed to evaluate the statistical significance of differences in mean condition factor between fish determined to be Ceratomyxa shasta-positive and C. shasta-negative by PCR. A 1-sided $t$-test was used to test the hypothesis that condition factor would decrease in diseased fish. Within each stock, results were grouped by sample date. For data groups where there were too few results in 1 category to conduct the statistical analysis, the $t$ test was not performed (for example, if 4 or fewer fish were negative for $C$. shasta). A statistical significance level of $5 \%$ was used.

\section{RESULTS}

\section{Infection prevalence}

Ceratomyxa shasta infection prevalence, as determined by PCR assay, was low during rearing on well

Table 1. Percent of steelhead Oncorhynchus mykiss and cutthroat trout $O$. clarki positive for Ceratomyxa shasta by polymerase chain reaction and severity of infection as determined by parasite number and lesion severity score. Fish stocks reared at Cowlitz Trout Hatchery during the 1998-99 brood year. Number of parasites were determined by examination of histological sections from 8 to 10 fish using the indirect fluorescent antibody technique. Average lesion scores of fish that were infected were based on a scale of 0 to 5 . ND = not determined

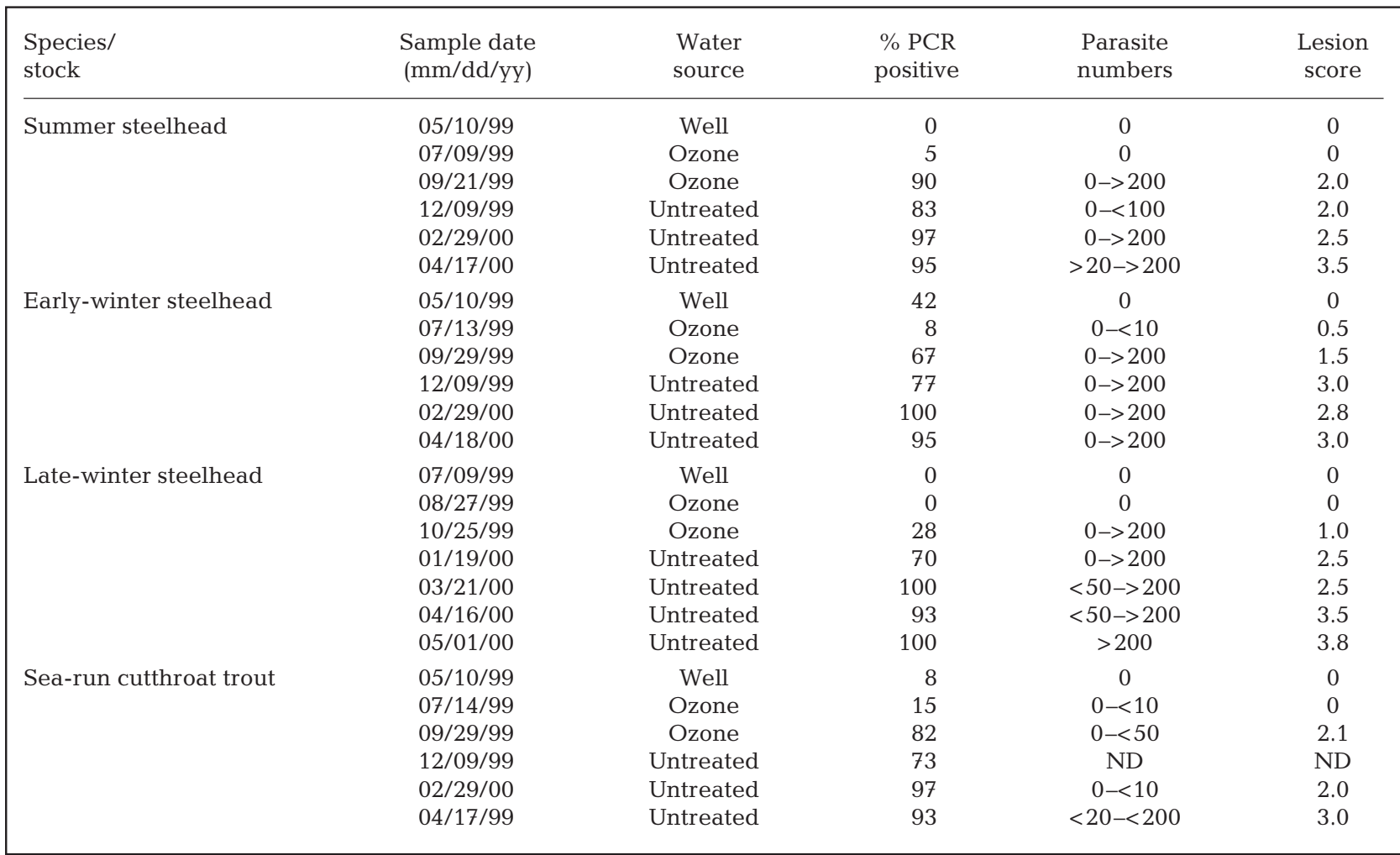




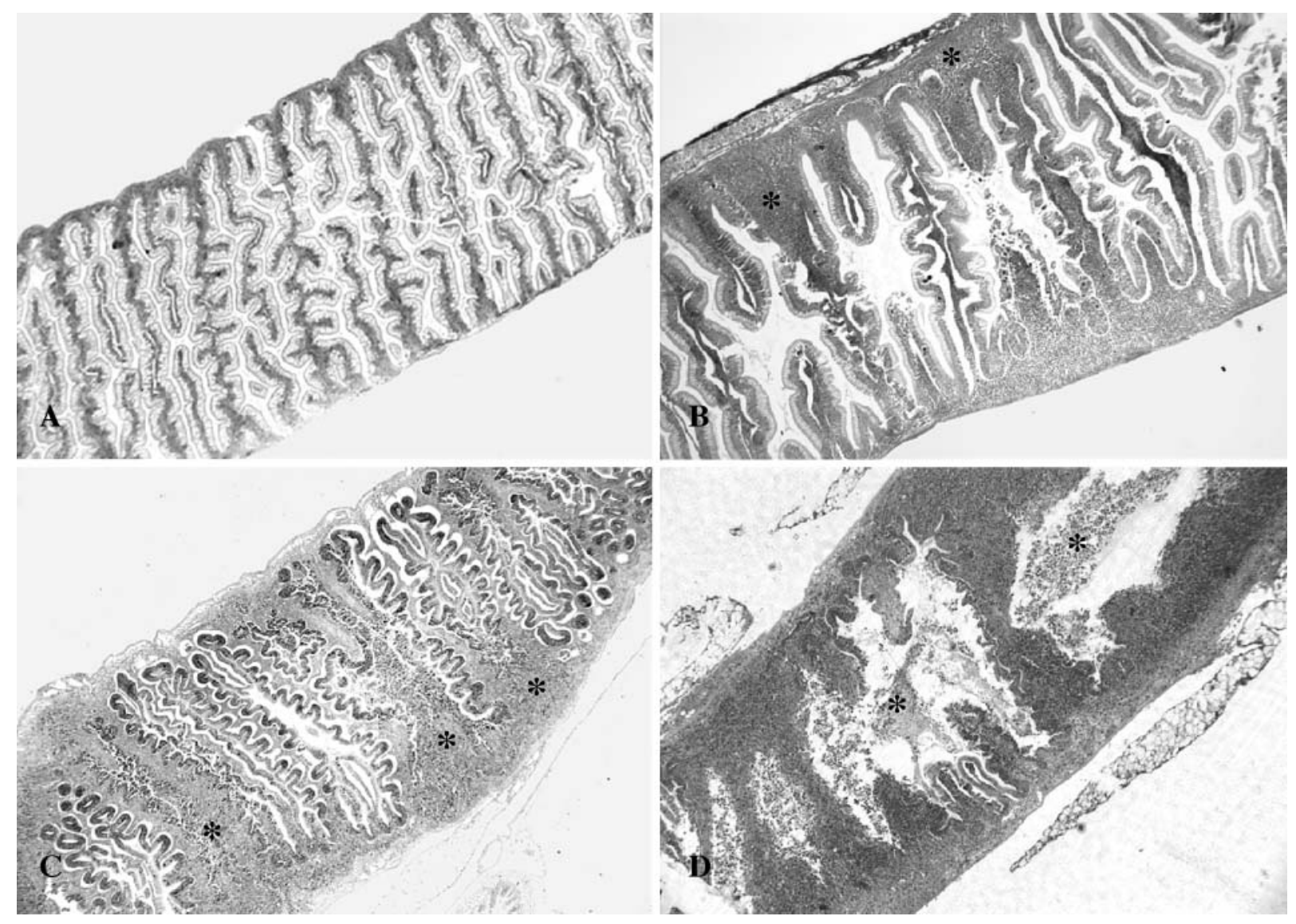

Fig. 1. Histopathology of Ceratomyxa shasta in Oncorhynchus mykiss. Longitudinal sections of intestine showing representative lesions for Grades: (A) 0, normal intestine; (B) 2, focal areas (*) of inflammation; (C) 4, multiple sites (*) of inflammation and parasite proliferation; and (D) 5, extensive parasite proliferation and necrotic host cells (*) occluding intestinal lumen

water, except among early-winter steelhead from the May sample (42\%) (Table 1, Fig. 2). However, the decreased incidence of infection in the subsequent sample $(8 \%)$ and the inability to detect infection by histology or by IFAT suggests that contamination of these samples may have occurred. If this data point is discounted, then all stocks follow a similar pattern. Infection prevalence remained low through the first sample period on ozone-treated water (July for summer and early-winter steelhead and cutthroat trout; August for late-winter steelhead). In subsequent samples, taken in September and October, prevalence rose to $90 \%$ for summer steelhead, $67 \%$ for earlywinter steelhead, and $82 \%$ for sea-run cutthroat despite ozone treatment of the water supply. Infection prevalence among late-winter steelhead remained low through November $(28 \%)$, when the water supply was no longer treated. The percent of fish infected continued to increase during the winter sampling periods when water was untreated, and in February and March infection prevalence was greater than
$95 \%$ for all stocks. Infection prevalence remained high through release.

\section{Infection severity}

Ceratomyха shasta infection severity was inferred from 2 measures: parasite number, as assessed by IFAT, and lesion severity (Table 1, Fig. 1). For earlywinter steelhead and sea-run cutthroat trout, infection was first detected by IFAT from fish sampled in July. Infection prevalence in July was low for these groups ( $8 \%$ of early-winter steelhead; $15 \%$ of cutthroat trout), and numbers of parasites per tissue section were fewer than 10. Histologically, parasites were present on the surface of the epithelial cells and infection was not associated with a host response (Fig. 3A). By September, parasites were present on the surface of epithelial cells and in the intestinal lumen (Fig. 4). Parasite numbers per tissue section were variable, but were generally higher in the steelhead $(0$ to $>200)$ than in 

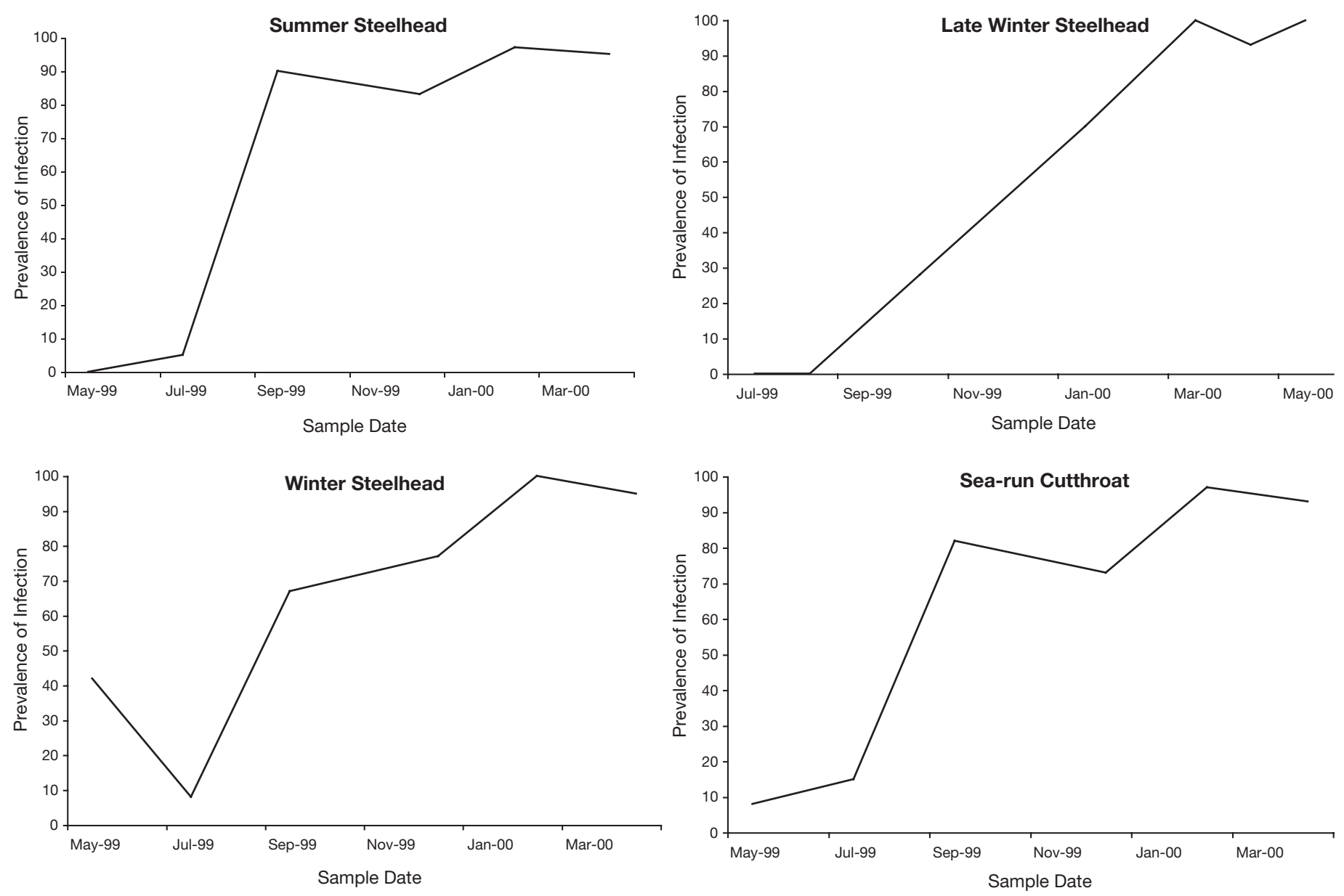

Fig. 2. Prevalence of Ceratomyxa shasta infection in 3 stocks of steelhead Oncorhynchus mykiss and sea-run cutthroat trout O. clarki reared at the Cowlitz Trout Hatchery

cutthroat trout $(0$ to $<50)$. Signs of granulomatous inflammation was evident in each stock, but was limited, and much of the tissue appeared normal (Fig. 3B). The average lesion score for each stock reflected the limited tissue response: summer steelhead 2.0, earlywinter steelhead 1.5, cutthroat trout 2.1. Parasite numbers remained high in fish sampled during winter (Table 1). Infection severity increased to moderate (lesion score 2.8 to 3 ) with a multifocal inflammatory response throughout the mucosa, areas of epithelial cell sloughing, and parasites and necrotic host cells present in the lumen (Fig. 3C).

Infection in late-winter steelhead followed the same pattern, but was delayed. A mild inflammatory response (average lesion score 1.0) was first noted in fish sampled during late October. Over subsequent sample periods, abundance of parasites on the mucosal surface remained high, and lesion severity increased.

At release, the average lesion severity for all stock ranged from 3.0 to 3.8. Presporogonic parasite stages were generally abundant (20 to $>500$ per section), but there was no evidence of further development to sporogonic stages. The inflammatory response in many fish was extensive, with severe tissue necrosis and mucosal damage (Fig. 3D), although in each stock there were individuals with tissue that appeared normal.

\section{Condition factor}

There was a significant difference $(\mathrm{p}<0.05)$ in mean condition factor between PCR-positive and -negative fish.

\section{DISCUSSION}

The use of molecular technologies for monitoring purposes remains controversial. One advantage is that these sensitive techniques allow detection of low numbers of parasites, often in the absence of clinical disease. However, it is not always clear what the presence 


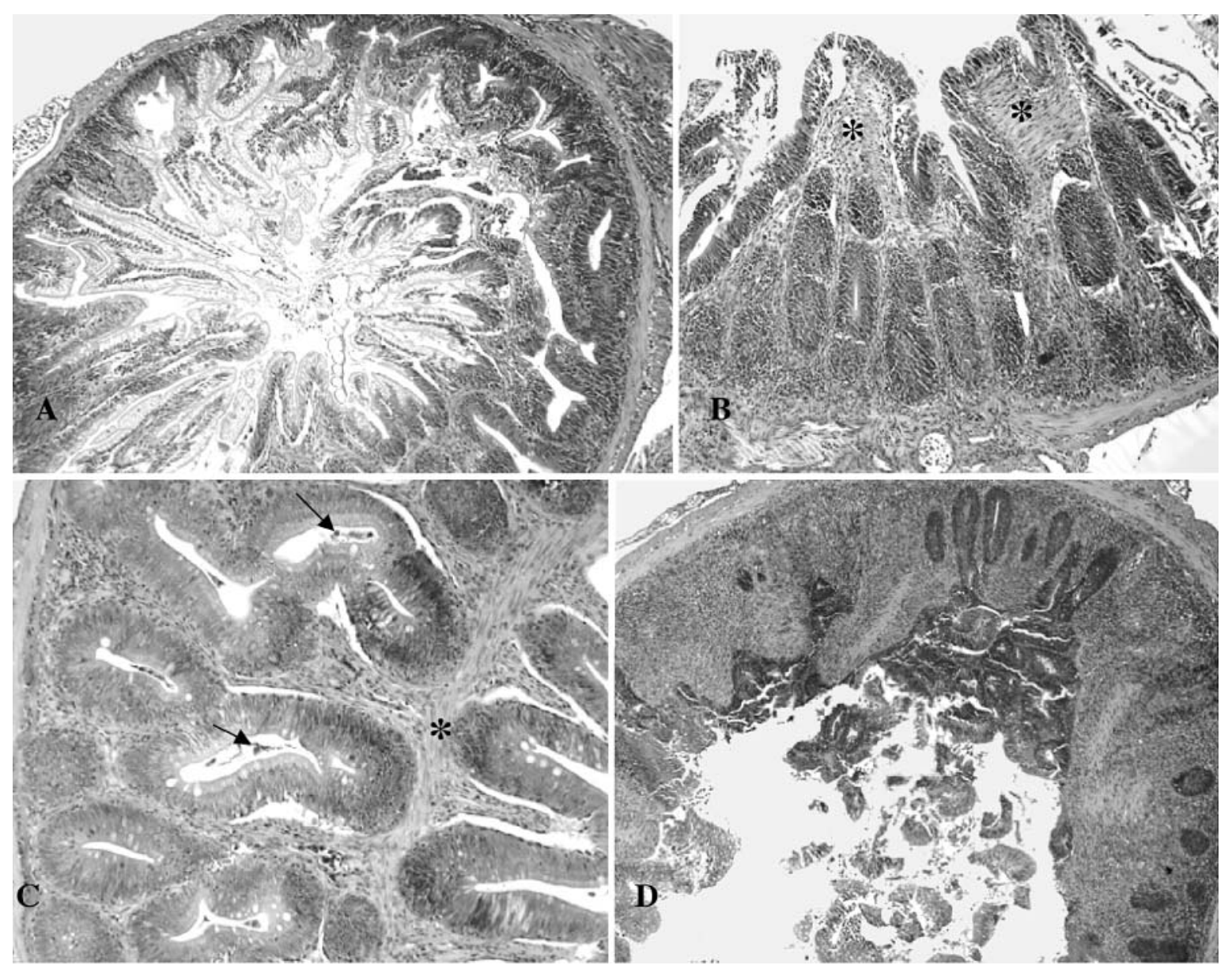

Fig. 3. Histological sections showing progression of infection associated with Ceratomyxa shasta in summer steelhead Oncorhynchus mykiss: (A) July sample, Grade 0 lesion; (B) September sample, Grade 2 lesion showing focal inflammation and fibrosis (*); (C) February sample, Grade 3 lesion showing diffuse inflammation, fibrosis (*) and numerous parasites (arrows); (D) April sample, Grade 4 infection showing severe inflammation and mucosal involvement

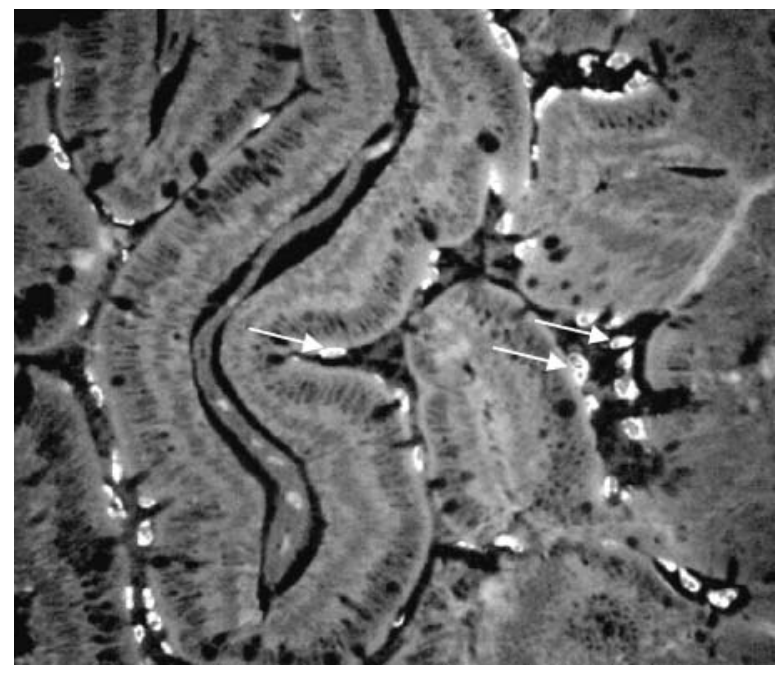

Fig. 4. Ceratomyxa shasta in summer steelhead Oncorhynchus mykiss. Histological section of posterior intestine showing detection of parasites on the surface of intestinal epithelial cells using an indirect fluorescent antibody technique of low pathogen numbers means biologically, or how this information should be used. The present study relates data on infection prevalence by PCR with other measures of infection and describes the biological significance of the infection. At the same time, this study also provides an example of how PCR methods can be used in a monitoring situation to inform hatchery operations.

For all 4 stocks of fish followed through their hatchery-rearing phase, detection of Ceratomyxa shasta infection using the PCR assay could be confirmed using serological methods and standard histological procedures, except at the earliest sampling periods. Infections during rearing on well water were detected by PCR at a low prevalence (with the exception of the anomalous result from the first assay of winter steelhead) and these findings could not be confirmed by histology or IFAT. Infection prevalence remained low ( 8 and $15 \%$ ) during the first sample period after fish were transferred to ozone-treated river water, but par- 
asites were detected serologically in these groups. This suggests that at the lowest infection levels PCR is more sensitive than other methodologies, and that PCR results can be used as an early indicator of infection.

A criticism of PCR-based detection methods is that they do not provide information on the biological significance or predicted outcome of pathogen detection. In this study, results of the PCR assay continued to correlate with histological and serological detection of Ceratomyxa shasta through the fall as the numbers of parasites and the lesion severity increased. Over the winter, when temperatures were below $10^{\circ} \mathrm{C}$, all measures of infection remained relatively stable, likely reflecting a low level of parasite proliferation at colder water temperatures. By release in the spring, infection prevalence among all stocks was greater than $90 \%$, and lesion scores were increased over the winter levels. Infection severity was similar for all stocks at release, despite the fact that late-winter steelhead were reared longer on well water. These findings are in contrast to data on infection prevalence collected prior to the advent of molecular technologies, when $C$. shasta was considered to be at low prevalence in these stocks. The increasing prevalence of infection as determined by PCR did correlate with the progression of the infection as measured by other methods in this study. However, increased mortality during rearing could not be directly attributed to these infections.

Development of clinical ceratomyxosis is dependent on a variety of factors, including strain susceptibility (Bartholomew 1998). Descriptions of the disease from susceptible and resistant strains of rainbow trout exposed to the parasite by a natural infection route for $3 \mathrm{~d}$ showed a marked difference in the response of the hosts (Bartholomew et al. 1989a). In the susceptible strain, parasites were detected between epithelial cells of the descending intestine as early as $7 \mathrm{~d}$ post-exposure. Lymphocytes infiltrated the tissue in response to the rapid proliferation of the parasite throughout the tissue layers. Necrotic host cells and parasites occluded the intestine in the late stages of infection, myxospores developed and mortality was high. In contrast, out of 150 individuals of a resistant strain of rainbow trout challenged simultaneously in that study, only 2 manifestations of Ceratomyxa shasta infection were noted, each in a single fish. In 1 fish, a presporogonic stage of the parasite was detected in the lumen of the posterior intestine, with no associated host response. The second fish was severely infected, with lesions similar to that described in the susceptible strain. In another study, Ibarra et al. (1991) noted granulomas surrounding degenerative parasite stages in a resistant strain of rainbow trout infected by intraperitoneal injection of parasite stages. These descriptions suggest that a variety of responses may contribute to resistance, including prevention of the parasite from invading and more efficient containment. Although these observations are limited, they support a hypothesis proposed by Ibarra et al. (1994), whereby resistance depends on 2 interacting mechanisms, the first exerting control over the initial stages of invasion or establishment, and the second involving the ability of the fish to mount an immune response. This study provided an opportunity to re-examine this hypothesis in resistant strains of 2 species having chronic C. shasta infections.

For both steelhead and cutthroat trout, infection was characterized by large numbers of parasites on the mucosal surface and by multiple foci of inflammation. Unlike Ceratomyxa shasta infections described from susceptible strains, the parasite did not migrate through the tissue layers, sporogenesis was not observed and there was little mortality associated with the infection. These observations support the hypothesis of a primary resistance mechanism that limits invasion. Support for the second part of this hypothesis, the ability of the fish to mount an immune response, is less clear. For all stocks, lesion severity progressed over the course of the study and there did not appear to be resolution of the infection.

Several studies have reported increased mortality among resistant strains with increasing exposure frequency (Ratliff 1981, Ibarra et al. 1994), indicating that disease resistance may be overcome when the infectious dose is high or exposure is prolonged. This may explain the high mortality (38 to $90 \%$ annually; Tipping 1988) that occurred among the Cowlitz steelhead and cutthroat trout stocks prior to the installation of the ozone treatment facility. The increased survival following installation of the ozone treatment facility demonstrates that the infectious dose has been reduced to a level that allows the fish to resist overt disease. However, the marked host response to parasite infection present in these fish at release would be an obvious contributing factor to the diminished body condition in PCR-positive fish. Severe granulomatous enteritis causes a disturbance in absorption and transport functions of the intestine, an event well described for a variety of diseases of several animal species (Barker et al. 1993). Protein-losing enteropathy, wasting and ascites are commonly associated with these debilitating lesions, and would negatively impact growth of the affected animal. As a result, Ceratomyxa shasta may affect post-release survival during migration and seawater acclimation either indirectly by decreasing fitness or directly as the disease progresses.

The pattern of Ceratomyxa shasta infections detected by PCR throughout the rearing cycle suggested that exposure occurs at more than 1 point. Detection of a low infection prevalence during rearing on well 
water indicated that some contamination of the water supply occurred, either through seepage from the adjacent river, or from the water distribution lines. Subsequent studies conducted at the hatchery demonstrated leakage of untreated river water into the wellwater pipeline. The high prevalence of infection during rearing on ozone-treated water also indicated failure of this system, which may occur during power outages, or as a result of high turbidity that decreases the effectiveness of the treatment. During subsequent investigations on the efficacy of ozone treatment at the hatchery, C. shasta infection was detected at a low prevalence $(10 \%)$ among susceptible cutthroat trout held for $50 \mathrm{~d}$ on treated water coming directly out of the stripping towers. This finding suggests that ozone treatment levels of $2 \mathrm{ppm}$ (15 min retention; $0.2 \mathrm{ppm}$ residual) may be below what is effective for complete removal of infectious parasite stages. Ozone treatment levels for the hatchery were based on a study by Tipping (1988), in which infection was determined by visual detection of the parasite, whereas in this study infection was determined using more sensitive molecular methods. Thus, in addition to providing information on the health status of the population, this study also demonstrates how molecular methods can be used to inform and improve hatchery operations.

Acknowledgements. The authors thank Tacoma Power for funding this study. Additional support for this project was provided by the U.S. Department of Agriculture under the Animal Health and Disease CRIS project no. ORE00038.

\section{LITERATURE CITED}

Barker IK, Van Dreumel AA, Palmer N (1993) The alimentary system; chronic inflammatory disease. In: Jubb KVF, Kennedy PC, Palmer N (eds) Pathology of domestic animals, Vol 2, 4th edn. Academic Press, New York, p 120-124

Bartholomew JL (1998) Host resistance to infection by the myxosporean parasite Ceratomyxa shasta: a review. J Aquat Anim Health 10:112-120

Bartholomew JL, Smith CE, Rohovec JS, Fryer JL (1989a) Characterization of the host response to the myxosporean parasite, Ceratomyxa shasta (Noble), by histology, scan-

Editorial responsibility: Wolfgang Körting,

Hannover, Germany ning electron microscopy, and immunological techniques. J Fish Dis 12:509-522

Bartholomew JL, Rohovec JS, Fryer JL (1989b) Ceratomyxa shasta, a myxosporean parasite of salmonids. USFWS Fish Dis Leafl 80, 8 p

Bartholomew JL, Rohovec JS, Fryer JL (1989c) Development, characterization, and use of monoclonal and polyclonal antibodies against the myxosporean Ceratomyxa shasta. J Protozool 36:397-401

Bartholomew JL, Whipple MJ, Stevens DG, Fryer JL (1997) The life cycle of Ceratomyxa shasta, a myxosporean parasite of salmonids, requires a freshwater polychaete as an alternate host. J Parasitol 83:859-868

Conrad JF, Decew M (1966) First report of Ceratomyxa in juvenile salmonids in Oregon. Prog Fish-Cult 28:238

Fox MD, Palenzuela O, Bartholomew JL (2000) Strategies for diagnosis of Ceratomyxa shasta using the PCR: comparison of lethal and non-lethal sampling with microscopic examination. J Aquat Anim Health 12:100-106

Hendrickson GL, Carlton A, Manzer D (1989) Geographic and seasonal distribution of the infective stage of Ceratomyxa shasta (Myxozoa) in northern California. Dis Aquat Org 7: 165-169

Ibarra AM, Gall GAE, Hedrick RP (1991) Susceptibility of two strains of rainbow trout Oncorhynchus mykiss to experimentally induced infections with the myxosporean Ceratomyxa shasta. Dis Aquat Org 10:191-194

Ibarra AM, Hedrick RP, Gall GAE (1994) Genetic analysis of rainbow trout susceptibility to the myxosporean, Ceratomyxa shasta. Aquaculture 120:239-262

Kent ML, Andree KB, Bartholomew JL, El-Matbouli M and 12 others (2001) Recent advances in our knowledge of the myxozoa. J Eukaryot Microbiol 48:395-413

Palenzuela O, Bartholomew JL (2002) Molecular tools for the diagnosis of Ceratomyxa shasta (Myxozoa). In: Cunningham C (ed) Molecular diagnosis of fish diseases. Kluwer Academic Publishers, Dordrecht

Palenzuela O, Trobridge G, Bartholomew JL (1999) Development of a polymerase chain reaction diagnostic assay for Ceratomyxa shasta, a myxosporean parasite of salmonid fish. Dis Aquat Org 36:45-51

Piper RG, McElwain IB, Orme LE, McCraren JP, Fowler LG, Leonard JR (1982) Fish hatchery management. US Fish and Wildlife Service, Washington, DC

Ratliff DE (1981) Ceratomyxa shasta: epizootiology in chinook salmon of central Oregon. Trans Am Fish Soc 110:507-513

Schafer WE (1998) Studies on the epizootiology of the myxosporidian Ceratomyxa shasta Noble. Calif Fish Game 54:90-99

Tipping JM (1988) Ozone control of ceratomyxosis: survival and growth benefits to steelhead and cutthroat trout. Prog Fish-Cult 50:202-210

Submitted: May 26, 2004; Accepted: August 24, 2004

Proofs received from author(s): November 5, 2004 